\title{
ANALYTICAL STUDY ON THE FACTORS OF CHANGE IN INCOME OF WOMEN LAC GROWERS IN SEONI - A CENTRAL INDIAN DISTRICT
}

\author{
MANOHER SARYAM ${ }^{1}$, MONI THOMAS ${ }^{2}$ \& S. K. AGRAWAL ${ }^{3}$ \\ ${ }^{I}$ Research Scholar, Department of Extension Education, Institute of Agricultural Sciences, BHU, Varanasi, India \\ ${ }^{2}$ Senior Scientist, Directorate of Research Services, JNKVV, Jabalpur, India \\ ${ }^{3}$ Professor, Department of Extension Education, JNKVV, Jabalpur, India
}

\begin{abstract}
Self-help groups (SHGs) are one of the important tools for the empowerment of rural women and improvement of their socioeconomic status in India. It also improves family income, decision making, self confidence among women and weaker sections of the society. The study of the change in annual household income of tribal women lac growers after two years of their venture into Lac production was undertaken during the years 2012-13 with forty respondents in Malhara Panchayat of Barghat Block, Seoni district, Madhya Pradesh, India. Lac is an export oriented Non-timber Forest Produce (NTFP). It produced mostly by tribal, sub-forest, forest and rain fed area of Jharkhand, West Bengal, Chhattisgrah, Madhya Pradesh, Orissa, Maharashtra, part of Uttar Pradesh, Andhra Pradesh, Gujarat and NEH region of the country. The study revealed that a maximum number of lac growers (60\%) were found young age, level of education (40\%) was illiterate and middle school, (40\%) marginal land holders, (60\%) medium training attended lac growers, (50\%) highest information seeking behavior among the respondents. After the adoption of Lac production, the Contribution of Lac growers to their annual household income varied from Rs. 75,000 to Rs. 1, 23,000. The study also found that age and occupation had a positive relationship, whereas landholding, number of trainings attended, information seeking behavior, extensive participation and economic motivation had been significant to an annual income of women lack growers.
\end{abstract}

KEYWORDS: Lac Production, Socioeconomic, Annual Household \& Tribal Women and SHGs

Received: May 12, 2017; Accepted: Jun 02, 2017; Published: Jun 23, 2017; Paper Id.: IJASRAUG20173

\section{INTRODUCTION}

Empowerment of women is one of very important issues in developing countries. As women are integral part of society, her status and participation in decision making as well as economic activities is very low. Self-help groups (SHG) play a very pivotal role in women empowerment by providing fundamental education; need oriented training, skills for self-employment, protection for women and self-awareness program. Thus, they are mainly concerned with the living standard of the women in the society.

Women, particularly in rural sector play an important role in micro-economic activities and development (Singh et al., 2013). They perform these activities, mostly individually and in isolated conditions and rarely as a group. However, their ability to innovate, multi-tasking and contribution to household income is remarkable. There are many instances where women SHGs have brought revolutionary chances by adopting enterprises. Dairy in Gujarat (Kathiriya. et al. 2013) Non- Timber Forest Produce collection and processing are few well acknowledged examples.

Similar to the above innovative group activities of women elsewhere, ten tribal women in a non descriptive village Malhara, in Barghat Block of Seoni District in Madhya Pradesh, India, who was working as farm laborers 
during cropping season (July to October) and as non farm laborers during lean period (November to June) were motivated to work in a group mode since 2006-2008. In the year 2009, this Group was motivated to adopt lack production on the over 8000 Palash trees (Butea monospermous) conserved by them on the Gram Panchayat land (Common resource's property). Thus, Mahalaxmi Adivasi Mahila Lac Utpadak (MAMLU) was formed. MAMLU members were supported technically, socially and through basic inputs for Lac production. They initiated a small way in the year 2009 under constant technical supervision of Lac specialist Dr Moni Thomas of Jawaharlal Nehru Krishi Vishwa Vidyalaya, Jabalpur. The input and market support was extended by Mr Komal Singh Bhagel of the Adarsh Lac Vikash Samuh, Janamkhari, Barghat Block, Seoni. The present study was conducted on MAMLU three years, i.e., in the year 2012-2013, after they adopted Lac production.

Lac is an export oriented Non-timber Forest Produce (NTFP). It is a natural resin secreted by Lac insect Kerria lack while feeding the sap of its host plants. It is produced mostly by tribals, in sub-forest, forest and rain fed areas of Jharkhand, West Bengal, Chhattisgrah, Madhya Pradesh, Orissa, Maharashtra and part of Uttar Pradesh, Andhra Pradesh, Gujarat and NEH region (Sharma et al. 1997). India is the largest lac producer has a share of 62 per cent of the world production of 44,000 metric tons (Ogle and Thomas, 2006). The annual lack production in India varied from 18,000 ton to 23,229 ton in 2006-07 ( $\mathrm{Pal}$ et al. 2007) and 21,935 tons in 2007-08 (Pal et al. 2010). About 80 per cent of the country's total lack production is exported, valued \$ 16-22 million earned in foreign exchange annually (Prasad et al. 2004), it earned a foreign exchange worth Rs. 15,262 lakhs (Ogle and Thomas, 2006).

\section{METHODOLOGY}

The present study was undertaken during the years 2013-14. 40 Respondents of the study were carried out in Malhara village, barghat block, Seoni district, Madhya Pradesh. Seoni district was purposively selected because of the economy of the district is forest based. Main Minor Forest Produce such as Lac, Bamboo, Mahua, Sitafal, Chirongi etc. Seoni is the largest producer of Lac in M. P. The Barghat block is the major lack producer comprises of 136 villages. There were more than four women lacking growers SHGs in Barghat. Mahalaxmi Adivasi Mahila Lac Utpadak (MAMLU) is a SHG of women Lac growers, formally constituted in the year 2010 in village Malhara. The village has a large tract of land with Palash (Butea monospermous) trees on which Lac is produced by Lac growers. MAMLU adopted lack production on the Palash trees in 2010. The lack production, improved their socioeconomic status. The present study was conducted in the analytical study on the factors of change in income of Women Lac Growers of the 10 participating (Women Lac growers) members of Mahalaxmi Adivasi Mahila Lac Utpadak SHG and thirty non-participating (Non Lac growers) (10Youth, 10-Middle age, 10-Old) were selected for their opinion about the members of the Mahalaxmi Adivasi Mahila Lac Utpadak SHG through group discussion and structured interview schedule. Analysis was done with the use of frequency, percentage, absolute change, relative change and Pearson's product movement correlation coefficient (' $r$ ')

\section{Pearson's Product Movement Correlation Coefficient ('r')}

The correlation coefficient (r) is a measure of the degree of closeness of the linear relationship between two variables. This statistic ' $r$ ' has been used to find out the relationship between both independent and dependent variables. To calculate ' $r$ ', following formula being used: 


$$
r x y=\frac{\sum x y-\left(\sum x\right)\left(\sum y\right) / n}{\sqrt{\left(\sum x^{2}-\frac{\left(\sum x\right)^{2}}{n}\right)}\left(\sum y^{2}-\frac{\left(\sum y\right)^{2}}{n}\right)}
$$

Where,

$\mathrm{n}=$ Number of respondents, $\mathrm{x}=$ Independent variables

$\mathrm{y}=$ Dépendent variables, $\mathrm{r}=$ Corrélation coefficient

$\sum x y=$ sum of the product of score of two variables

$\sum \mathrm{x}=$ sum of $\mathrm{x}$ scores, $\sum \mathrm{y}=$ sum of $\mathrm{y}$ scores

$\sum \mathrm{x}^{2}=$ sum of the square of $\mathrm{x}$ scores, $\sum \mathrm{y}^{2}=$ sum of the square of $\mathrm{y}$ scores

$\left(\sum \mathrm{x}\right)^{2}=$ square of the summation of the independent variables

$\left(\sum y\right)^{2}=$ square of the summation of the dependent variables

\section{Absolute Change}

Absolute change was obtained by the difference between change occurs after and before the condition.

Absolute change $=$ income after Lac production - income before Lac production

\section{Relative Change}

Relative change obtained from the absolute change divided by before condition and multiple of 100 .

$$
\text { Income before Lac Production - income after Lac Production }
$$

Relative change $-\mathrm{X} 100$

\section{Income before Lac Production}

For the analysis of constraints in lack production was analyzed by using Garret-ranking technique. In this technique is the respondents were asked to rank each of the constraint relevant to them according to the degree of importance as perceived by them. As all the items were not ranked it by all the respondents the method of combining of incomplete order of merit ratings as suggested by Garret (1981) was followed.

\section{As suggested by Garret (1981) per cent position $=\mathbf{1 0 0}(\mathbf{R - 0 . 5}) / \mathbf{N}$}

Where, $\mathrm{R}$ is the rank of the individual item in the series and $\mathrm{N}$ is the number of individual items ranked.

Score for each of the factors after transmutation of orders of merit as per Garret (1981) was found out. To obtain the final order of merit, the scores for all the respondents for each of the factors were summated and the mean value was calculated. In finding out the mean values, the sum of the scores for each item was divided by its frequency of responses. The mean scores were calculated for each constraint and the appropriate rank was given accordingly. 


\section{RESULTS AND DISCUSSIONS}

The Profile of Members of Mahalaxmi Adivasi Mahila Lac Utpadak SHG

The age of 10 participating (Women Lac growers) varied from 28 to 52 years and youth predominant $(60 \%)$ followed by middle age (20\%) and old age members (20\%) (Table 1) Illiterate and middle school educated members consisted of 40 per cent each in the group while only 20 percent were high school educated. All the women lack growers were landholders and varied from marginal to large holders. Lac growers with marginal land holding predominated (40\%), followed by medium (30\%), small (20\%) and large land holding (10\%) Among the extension activities, participation of Lac growers in training programme on Lac production was highest. Majority of Lac growers (60\%) participatory training program Information is the key to any enterprise and so is the source of information. Majority of Lac growers (50\%) had high information seeking behavior followed by low (30\%) and medium (20\%) information seeking behavior. Participation of beneficiaries in extension activities, organizes formed an important platform for the exchange of information and experiences. Cent percent Lac growers had high extension participation. Economic motivation is the main driving force of much entrepreneurship. Majority of Lac growers had high motivation (40\%) followed by 30 percent each with medium and low motivation.

Table 1: The Profile of Members of Mahalaxmi Adivasi Mahila Lac Utpadak SHG (N=10)

\begin{tabular}{|c|c|c|c|}
\hline S. No & Categories & No. of Lac Growers & Percentage \\
\hline & & Frequency & Percentage \\
\hline \multirow[t]{4}{*}{1.} & \multicolumn{3}{|l|}{ Age Groups } \\
\hline & Young (up to 35 years) & 6 & 60 \\
\hline & Middle (36 to 50 years & 2 & 20 \\
\hline & Old (above 50 years) & 2 & 20 \\
\hline \multirow[t]{4}{*}{2.} & \multicolumn{3}{|l|}{ Level of Education } \\
\hline & Illiterate & 4 & 40 \\
\hline & Middle school & 4 & 40 \\
\hline & High school & 2 & 20 \\
\hline \multirow[t]{5}{*}{3.} & \multicolumn{3}{|l|}{ Size of Land Holding } \\
\hline & Marginal (up to 1 ha.) & 4 & 40 \\
\hline & Small (>1 to 2 ha.) & 2 & 20 \\
\hline & Medium (>2 to 5 ha.) & 3 & 30 \\
\hline & Large (>5 ha.) & 1 & 10 \\
\hline \multirow[t]{3}{*}{4.} & \multicolumn{3}{|c|}{ Training Attended on Lack Production } \\
\hline & Low (up to 3 scores) & 4 & 40 \\
\hline & Medium (4 to 5 scores) & 6 & 60 \\
\hline \multirow[t]{4}{*}{5.} & \multicolumn{3}{|c|}{ Information Seeking Behavior } \\
\hline & Low (up to 7 scores) & 3 & 30 \\
\hline & Medium (8 to 10 scores) & 2 & 20 \\
\hline & High (above 10 score) & 5 & 50 \\
\hline \multirow[t]{4}{*}{6.} & \multicolumn{3}{|l|}{ Extension Participation } \\
\hline & Low (up to 3 scores) & 0 & 00 \\
\hline & Medium (4 to 5 scores) & 0 & 00 \\
\hline & High (above 5 score) & 10 & 100 \\
\hline \multirow[t]{4}{*}{7.} & \multicolumn{3}{|l|}{ Economic Motivation } \\
\hline & Low (up to 24 scores) & 3 & 30 \\
\hline & Medium (25 to 26 scores) & 3 & 30 \\
\hline & High (above 26 scores) & 4 & 40 \\
\hline
\end{tabular}




\section{CONTRIBUTION IN ANNUAL HOUSEHOLD INCOME OF THE LACK GROWERS}

Before the adoption of Lac production, the Lac grower's annual household income (AHI) varied from Rs. 28,000 to Rs. 65,000. Prior to the adoption of Lac production, the contribution of Lac growers to their AHI was low and varied from 18.46 to 37.14 percent with a mean of 31.41 per cent. After the adoption of Lac production, their contribution to AHI increased and it varied from Rs. 75,000 to Rs. $1,23,000$, i.e. 40.64 to 60.29 per cent against their earlier contribution of 18.46 to 37.14 per cent (Table 2). The increase in AHI over their earlier varied from 47.15 per cent to 63.15 per cent with a mean of 54.81 per cent. The increase in contribution of annual household income varied from Rs 75,500 to 1, 23,000 per year.

Table 2: Contribution in Annual Household Income of the Lac Growers

\begin{tabular}{|c|c|c|c|c|c|c|c|c|c|c|c|}
\hline \multirow{4}{*}{ S.Noo } & \multirow{4}{*}{ Lack'Growerso } & \multicolumn{8}{|c|}{ Contribution'In'Annual Household Incomeo } & \multicolumn{2}{|c|}{ Increase'In'(\%) )a } \\
\hline & & \multicolumn{4}{|c|}{ Beforea } & \multicolumn{4}{|c|}{ Aftero } & \multirow{3}{*}{$\begin{array}{l}\text { House } \\
\text { Holdo }\end{array}$} & \multirow{3}{*}{ Contributiono } \\
\hline & & \multirow[t]{2}{*}{ Categoryo } & \multirow{2}{*}{$\begin{array}{r}\text { Household } \\
\text { Incomen }\end{array}$} & \multicolumn{2}{|c|}{$\begin{array}{c}\text { Contribution' } \\
\text { of 'WLGso }\end{array}$} & \multirow[t]{2}{*}{ Categoryo } & \multirow[t]{2}{*}{ Household Incomer } & \multicolumn{2}{|c|}{ Contribution of 'WLGso } & & \\
\hline & & & & Rs.D. & $\%$ & & & Rsio & $\%$ & & \\
\hline 10 & Kushmad" & (A) 0 & 350000 & 100000 & $28.57 \%$ & $(A+L) a$ & 770000 & 425000 & 55.190 & 54.540 & 76.470 \\
\hline 20 & Rampyario & $(A+L b) a$ & 280000 & 80000 & $28.57 \%$ & $(A+L+L b) a$ & 755000 & 455000 & 60.290 & 62.510 & 82.410 \\
\hline 30 & Indrä & $(A+L b) a$ & 350000 & 120000 & 34.280 & $(\mathrm{~A}+\mathrm{L}+\mathrm{Lb}) \mathrm{a}$ & 815000 & 4750000 & 58.280 & 57.050 & 74.730 \\
\hline 40 & Kalibain & $(A+L b) a$ & 350000 & 130000 & 37.140 & $(A+L) a$ & 820000 & 405000 & 49.390 & 57.310 & 67.900 \\
\hline 50 & Sunital & $(A+L b) 0$ & 420000 & 150000 & 35.510 & $(\mathrm{~A}+\mathrm{L}+\mathrm{Lb}) \mathrm{a}$ & 835000 & 435000 & 52.090 & 49.700 & 65.510 \\
\hline 60 & Kanya'Kumario & (A) 0 & 650000 & 120000 & 18.460 & $(A+L) 0$ & 1230000 & 500000 & 40.650 & 47.150 & 760 \\
\hline 70 & Laxmio & $(A+L b) a$ & 350000 & 110000 & 31.420 & $(A+L) 0$ & 835000 & 445000 & 53.290 & 58.080 & 75.280 \\
\hline 80 & Hansad & $(A+L b) a$ & 490000 & 130000 & 26.510 & $(A+L+L b) a$ & 1035000 & 450000 & $43.47 \%$ & 52.650 & 71.110 \\
\hline 90 & Chandra kalao & $(A+L b) 0$ & 350000 & 130000 & 37.140 & $(\mathrm{~A}+\mathrm{L}+\mathrm{Lb}) \mathrm{a}$ & 950000 & 400000 & 42.100 & 63.150 & 67.500 \\
\hline 100 & Chadrawatio & $(A+L b) a$ & 350000 & 130000 & 37.140 & $(A+L+L b) a$ & 835000 & 425000 & $50.89 \%$ & 58.080 & 69.410 \\
\hline
\end{tabular}

A-Agriculture; Lb-waged, Labor; L-Lac

\section{ZERO ORDER CORRELATION BETWEEN INDEPENDENT VARIABLES (XS) AND INCREASE IN ANNUAL INCOME (y1) OF LACK GROWERS}

In the present study, 12 independent variables viz., age (X1), education (X2), land holding (X3), occupation (X4), access to Palash trees (X5), number of training attends (X6) information seeking behavior (X7), extensive participation (X8), economic motivation (X9), innovativeness (X10), knowledge level (X11), aspiration level (X12) were taken into consideration and correlated with the dependent variable i.e., increase in annual income (Y1). The correlation of each of the independent variables with the dependent variable is as follows. (Table 3) The age (X1) of the Lac growers and their increase in the annual income (Y1) had no significant correlation ( $r=0.449)$. Therefore, it can be concluded that age and increase in income has no correlation. According to the education level the Lac growers there were seven categories. The education level (X2) and their increase in the annual income (Y1) had a negative correlation ( $\mathrm{r}=-0.163)$. There were four categories of Lac grower's namely marginal, small, medium and large landholders. The Landholding (X3) of Lac growers and their increase in annual income (Y1) had significant correlation ( $\mathrm{r}=0.639 *$ at 0.05 level of probability). Thus, the Landholding of the Lac growers had a positive significant relationship with increase in their annual income. La production 
(X4) of the Lac growers and their increase in annual income (Y1) had no significant correlation ( $\mathrm{r}=0.395)$. Therefore, it can be concluded that occupation of the Lac growers and their increase in annual income had no correlation. The number of training attended by the Lac growers (X6) and increase in their annual income (Y1) had high significant correlation $\left(r=0.700^{*}\right.$ at 0.05 level of probability). Thus, the number of training attended by the Lac growers had a positive significant relationship with the increase in their annual income. Lac growers of MAMLU SHG had access to information seeking behavior from six sources. Their information seeking behavior (X7) and increase in their annual income (Y1) had high significant correlation $\left(\mathrm{r}=0.715^{*}\right.$ at 0.05 level of probability). Thus the information seeking behavior of Lac growers had a positive significant relationship with the increase in their annual income. There were eight events to measure the extension participation of Lac growers. The extensive participation (X8) and increase in their annual income (Y1) had significant correlation $\left(\mathrm{r}=0.657^{*}\right.$ at 0.05 level of probability). Thus the extent of participation in extension activities of the Lac growers had a positive significant relationship with the increase in their annual income. There were three levels of economic motivation (low, medium and high) among Lac growers. The level of economic motivation (X9) among Lac growers and increase in their annual income (Y1) had significant correlation $\left(r=0.660^{*}\right)$. Therefore, economic motivation of the Lac growers and increase in their annual income had a positive correlation. There were three levels of innovativeness (low, medium and high) among Lac growers. Their innovativeness (X10) and increase in their annual income (Y1) had significant correlation ( $\mathrm{r}=0.662 *$ at 0.05 level of probability). Thus, innovativeness and an increase in the annual income of Lac growers had a positive correlation. Knowledge level of Lac growers was identified during the study and it was found that the knowledge level (X11) and increase in annual income (Y1) had significant correlation (r=0.686* at 0.05 level of probability). Thus, it is evident that the knowledge level of Lac growers had a positive significant relation with their increase in annual income. Aspiration level of Lac growers was identified during the study and it was found that the aspiration level (X12) and increase in annual income (Y1) had significant correlation ( $\mathrm{r}=0.703 *$ at 0.05 level of probability). Thus, it is evident that the aspiration level of Lac growers had a positive significant relation with their increase in annual income.

\section{Table 3: Zero Order Correlation between Independent Variables (XS) and} Increase in Annual Income (y1) of Lack Growers

\begin{tabular}{|l|l|c|}
\hline \multicolumn{2}{|c|}{ Independent Variables } & $\begin{array}{c}\text { Dependent Variable Increase } \\
\text { In Annual Income(y1) }\end{array}$ \\
\hline $\mathrm{X}_{1}$ & Age & 0.449 \\
\hline $\mathrm{X}_{2}$ & Education & -0.163 \\
\hline $\mathrm{X}_{3}$ & Land is holding & $0.639^{*}$ \\
\hline $\mathrm{X}_{4}$ & Lac Production & 0.395 \\
\hline $\mathrm{X}_{5}$ & Access of Palash trees & - \\
\hline $\mathrm{X}_{6}$ & Number of training attends & $0.700^{*}$ \\
\hline $\mathrm{X}_{7}$ & Information seeking behavior & $0.715^{*}$ \\
\hline $\mathrm{X}_{8}$ & Extension participation & $0.657^{*}$ \\
\hline $\mathrm{X}_{9}$ & Economic motivation & $0.660^{*}$ \\
\hline $\mathrm{X}_{10}$ & Innovativeness & $0.662^{*}$ \\
\hline $\mathrm{X}_{11}$ & Knowledge level & $0.686^{*}$ \\
\hline $\mathrm{X}_{12}$ & Aspiration level & $0.703^{*}$ \\
\hline Significant at 0.05 level of probability $* *$ Significant at 0.01 level of probability
\end{tabular}

\section{PROBLEM FACED BY PARTICIPATING WOMEN IN LACK PRODUCTION}

The adoption of lack production, improved their social- economic status of lack growers in Malhara village (Table 4). However, the faced four major constraints such as theft of lack of maturity ranked first due to lack of boundary in the 
lack production site. Second rank high summer temperature faced by lack growers followed by third rank problem faced by lack growers was untimely lack harvest because of No place for storage in the field and the scarcity of labor and another was less equipment for proper harvesting of raw $\log$.

Table 4: Problem Faced by Participating Women Lack Growers in Lack Production

\begin{tabular}{|c|l|l|c|}
\hline S. No. & \multicolumn{1}{|c|}{ Problems } & \multicolumn{1}{c|}{ Causes } & Ranking \\
\hline 1. & High summer temperature & With no irrigation & II \\
\hline 2. & Untimely harvest & $\begin{array}{l}\text { No place for storage in the } \\
\text { field }\end{array}$ & IV \\
\cline { 3 - 4 } & Scarcity of labor & III \\
\hline 3. & With less equipment & Lack of proper harvesting & V \\
\hline 4. & Theft of Lac & $\begin{array}{l}\text { Lack of boundary in the } \\
\text { production at the site }\end{array}$ & I \\
\hline 6. & $\begin{array}{l}\text { Non-availability of inputs in } \\
\text { local and nearby markets. }\end{array}$ & Distance of field areas & VI \\
\hline 7. & $\begin{array}{l}\text { Lack of information on current } \\
\text { price of lack. }\end{array}$ & Lack of awareness & VII \\
\hline 8. & Lack of grading facility & Weighing machine & VIII \\
\hline
\end{tabular}

\section{CONCLUSIONS}

The lac production has been found to play an important role in the case of trained than untrained lack growers. There is a need for strengthening the extension activity to increase the annual income through with scientific knowledge on lack cultivation so as to increase income and employment generation at the field level. Non-timber forest products must be used in an Eco friendly way. Livelihood and strengthening of rural level institutions to build their understanding of the economic value of lack cultivation should be attempted. The government should promote local storage facilities and processing units by the forest dwellers themselves, and bring a large number of buyers in touch with the gatherers, in order to reduce the layers of intermediaries (Saxena, 2003). In this way, lack cultivation could serve to increase the income of forest villagers, which would help ensure their livelihood security and their life style.

\section{REFERENCES}

1. Jaiswal A K, Pal G, Singh J P and Patel B. 2010. Growth analysis of lac production in Madhya Pradesh The Indian Forester 139 (5): 448-452.

2. Jaiswal A K, Pal G, Singh J P and Patel B. 2012. Lac production growth analysis for the state of Odisha Bio-ved 23 (1): 15.

3. Kathiriyal J B, Damasia D M and Kabaria B B. 2013 Role of rural women in dairy farming of Rajkot district Tamilnadu Journal of Veterinary \& Animal Sciences 9 (4): 239 - 247.

4. Ogle A and Thomas M. 2006. Technical consultancy report on strategic development of lack in Madhya Pradesh Enter plan UK $61 \mathrm{pp}$.

5. Pal G, Bhagat M L and Bhattacharya A. 2010. Yield gap and constraints in adoption of improved lack cultivation technology in Jharkhand. Indian Journal of Forestry 33 (4): 609-612.

6. Pal G, Jaiswal A K and Bhattacharya A. 2007. Lac statistics at a glance 2007 IINRG, Ranchi, Jharkhand

7. Pal G. 2011. Socio-economic characteristics of lack growers in Kanker district of Chhattisgarh. Indian Forester 137 (11):1294-1297. 
8. Patidar N. 2011. Assessment of the role of Madhya Bharat Lac Utpadhak Sangh in dissemination of Lac production technology and its impact on Lac growers of Mediaraas village Anuppur district, Madhya Pradesh M.sc. (Ag), Thesis, submitted, JNKVV, Jabalpur.

9. Prasad, 2011 Strategy for Sustainable NTFP Management in India International Conference on NWFP for Sustained Livelihood Bhopal- India Pp-1

10. Prasad, 2011 Strategy for Sustainable NTFP Management in India International Conference on $\quad$ NWFP for Sustained Livelihood Bhopal- India Pp-1

11. Ramani, 2010 National Strategy For Enhancing Lac Production in compilation of talks on Foundation day Conference of Stakeholders Current Issues Related to Lac Production in IINGR, Ranchi, pp. 1-3.

12. Saxena N C. 2003. From monopoly to de-regulation of NTFPs: Policy shifts in Orissa (India). The International Forestry Review, 5(2), 168-176. Retrieved from www.cifor.org/publications/pdf_files/polex/Psaxena0301.pdf

13. Sequeira V and Bezkorowajnyj P G 1998 Improved management of Butea monospermous (Lam.) Taub for lack production Forest Ecology and Management 102: 225-234

14. Sharma K K, Jaiswal A K, Bhattacharya A, Mishra Y D and Sushil S N. 1997. Emergence profile and relative abundance of parasitoids associated with Indian lack insect Kerria lack (Kerr.) Indian Journal Ecology 24 (1): 17-22.

15. Singh S, Thakur G and Gupta P C 2013 A Case Study on Empowerment of Rural Women through Micro Entrepreneurship Development Journal of Business and Management 9: 123-126.

16. Thomas M, Khare VR, Shukla P K, Srivastava $R$ and Dave R. 2011 Impact of promotion of Lac cultivation on rural livelihoods and forest conservation in Madhya Pradesh International Conference on NWFP for Sustained Livelihood BhopalIndia Pp-30

17. Thomas, 2012 Lac Cultivation for Improving Micro-Agro Eco System and Local Rural Economy in training programme on Advance in Agro-technologies for Improving Soil, Plant and Atmosphere Systems, JNKVV, pp 288-289 